\title{
PEMIKIRAN EKONOMI DAN BISNIS
}

"The focus on the sustainability of lobster in Indonesia as a result of Minister of Marine Affairs and Fisheries Regulation Number 12 of 2020"

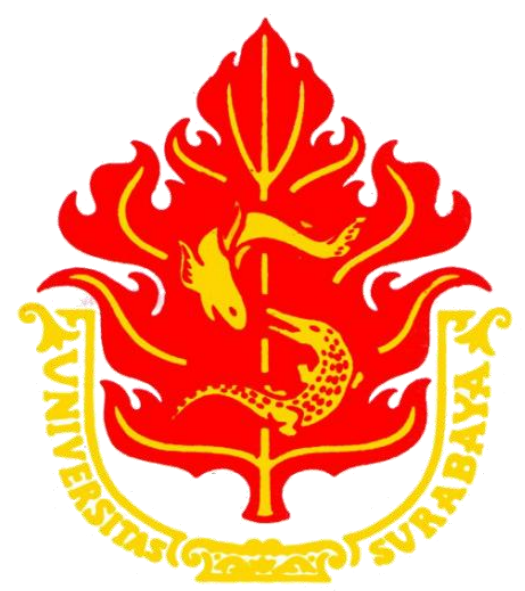

Oleh :

Lely Puspitasari Adinoto

130218124

KP B

FAKULTAS BISNIS DAN EKONOMIKA

UNIVERSITAS SURABAYA

2021 
"The focus on the sustainability of lobster in Indonesia as a result of Minister of Marine Affairs and Fisheries Regulation Number 12 of 2020"

According to A.Z. Tayibnapis and L.E. Wuryaningsih, the Indonesian government through the Ministry of Marine Affairs and Fisheries revised 18 regulations in the field of fisheries, one of which is through the Minister of Marine Affairs and Fisheries Regulation Number 12 of 2020 concerning Management of Lobster and Crab in the Territory of the Republic of Indonesia. The existence of this regulation has actually caused unrest among stakeholders because the government has authorized fishing gear that was previously prohibited to be used on the grounds that it wants to help 13,000 small fishermen who have lost their livelihoods.

According to the Ombudsman of the Republic of Indonesia, the policy that allows the export of lobster seeds is not in accordance with the mandate of the economic constitution as stipulated in Article 33 of the 1945 Constitution paragraph 3 and paragraph 4 with the argument that lobster seeds are an extractive natural resource because they are taken from nature, and are usually produced from hatcheries. The government's policy of opening lobster seed exports and legalizing fishing gear, such as cantrangs and the like, is feared to trigger a horizontal conflict between fishermen that is increasingly widespread.

Price movements for lobsters and lobster seeds are largely determined by developments in demand and supply, both at home and abroad. The report of the Roma group in "The Limits to Growth" (Meadow, 1972) shows that it is likely that the world will experience failure because important natural resources are very limited, while the level of world consumption continues to increase. Several renewable natural resources have suffered a lot of damage and pollution. However, renewable natural resources are different from non-renewable natural resources. Natural resources that are renewable can naturally be created again as long as exploitation by humans does not reach the point of extinction, but this will not happen to natural resources that are not renewable. In addition, the environmental capacity is also increasingly limited, for example lobster resources 
in 11 fisheries management areas in Indonesia are in the red zone and the yellow zone. This means that the harvesting of adult lobsters should not be increased and the catching of lobster seeds must be done very carefully.

Minister of Marine Affairs and Fisheries Regulation No.12 of 2020 explains that exporters are required to carry out lobster cultivation activities in the country by involving the community or local cultivators. This is considered to be beneficial for all parties, even the value of lobster production is targeted to be 303 billion rupiah in 2020 and increase to 1.73 trillion rupiah in 2024.

The bad thing is, shrimp farming business actors complain about convoluted business regulations. Several permits that many cultivators complain about are the Perda which states that cultivation ponds including buildings and levies are calculated per square meter. The existence of business rules based on the Minister of Marine Affairs and Fisheries Regulation Number 12 of 2020 certainly cannot be enforced in 2020 because this policy is related to Government Regulation Number 75 of 2015 concerning Types and Rates of PNBP which are not relevant longer now and in the future.

In reality, the roadmap for lobster cultivation in Indonesia 2020-2024 looks very optimistic and tends to ignore conditions in the field. The existence of an unreasonable $140 \%$ increase in price made lobster cultivators not believe it. Since the issuance of Minister of Marine Affairs and Fisheries Regulation No.12 of 2020, the fate of lobster cultivators has worsened because the price of harvested lobsters has fallen sharply and it is difficult to sell them. Strategic steps that can be taken by the central government are to postpone the implementation of new policies, simplify central and regional licensing, stop the export of lobster seeds, reduce the risk of death of marine mammals, to choose more environmentally friendly lobster fishing gear, and structuring partnership patterns so that there is legal certainty. for cultivators and fishermen. 
Source :

Tayibnapis, A.Z., Wuryaningsih, L.E., Gora, R. (2020). The impact of minister of marine affairs and fisheries regulation number 12 of 2020 on the sustainability of lobster in indonesia. International Journal of Multicultural and Multireligious Understanding, Vol. 7, No. 9. 